\title{
Camarín 19
}

\section{Los caminos hacia la tecnología y un nuevo orden}

\section{Mariana Pensa}

Camarín 19, la obra de Vera Czemerinski estrenada en la presente temporada del Teatro Nacional Cervantes como parte del ciclo Nuestro Teatro, y con el formato de teatro grabado, es una autorreflexión que problematiza la mediatización del teatro con lo tecnológico. Dos personajes, Reina y Clara, penetran en un teatro oscuro y desolado. Están solas y una sensación extraña las recorre, ya que no han encontrado a nadie más en su recorrido hacia su camarín, el 19. Reina, muy pronto, descubre una cámara invasora, un ojo que las mira, que las espía al tiempo que se maquillan y visten para la función que vienen a presentar. Mientras realizan estos ritos, esta rutina, rememoran su carrera, haciendo partícipes a esa cámara de una parte de la vida de ambas. Los recuerdos del pasado, que están teñidos por una imaginación que distancia y al mismo tiempo hace reconocibles ciudades y obras (un viaje a "Nueva Yol", el teatro en la "Quinta Vendida", las actuaciones en "Eldipo" y "Ortelo"), se entremezclan con el presente que ahora están percibiendo y padeciendo: el de esa cámara omnipresente que es, al decir de Reina, algo "fantasmal", "un bicho raro", "un agujerito, un túnel", un artefacto que las atrae y las repugna, al mismo tiempo. En ese universo-otro, todo ha sido vaciado de lo conocido, lo familiar: ese "coso", esa cámara fagocitante, clas aplaudirá al final?, reflexionan, entre curiosas y alarmadas. Ruidos, interrupciones, apagones y una voz distorsionada que llega de un altoparlante van marcando esa nueva experiencia escénica. "¿Será un cambio de formato?”, se pregunta lúcidamente Reina, tratando de acomodarse a esos nuevos signos sonoros y visuales. Si la deshumanización está presente en esa voz que dice palabras ininteligibles, entrecortadas, también lo está en la falta de público, del rastro humano que completa la experiencia teatral: ¿es esto, entonces, teatro? Si el teatro está mediatizado, ahora, por esa cámara, ¿es esto, todavía, teatro? En este nuevo orden pandémico en el que estamos viviendo, la respuesta sería que sí.

Reina y Clara problematizan ese nuevo orden, al estar estar inmersas en él, y es desde su propio entendimiento que pueden tratar de navegarlo. Si la cámara es una invasora, algo deshumanizado que le ha quitado, a través del acto insensible de la grabación, toda la inmediatez que la experiencia teatral tiene es también una nueva amiga que las pone en contacto con el público. Además, hay algo fundamental en esta nueva ecuación y son ellas mismas, dos actrices preparándose para ofrecer lo que saben hacer. Por eso, cuando ese aséptico asistente, la voz que llega del altoparlante, les dice, ahora, claramente: "Prevenidos para actuar, en cinco minutos empieza la función", no hay dudas en ellas que deben salir al ruedo. La impronta naif del final, 
ese baile que representan frente a un telón pintado, señala que el show, una vez más, debe seguir, debe continuar a pesar de todo. Las formas habrán cambiado, se habrán aggiornado, pero el espíritu permanece.

\section{FICHA TÉCNICA}

Camarín 19

Dramaturgia: Vera Czemerinski/Intérpretes: Reina: Noralih Gago, Clara:

Vanessa Maja, Voz on off: Matías López Stordeur/Vestuario: Juan Mario Roust/

Iluminación: Facundo David/Dirección de cámara y fotografía: César Iñiquez,

Santiago Abate, Facundo Trimarco, Sol Alleac/Escenografía: Jorge Ferrari/

Coreografía: Celia Argüello Rena/Dirección: Alejandra Flechner 